\title{
Integration of Simulators 5th Level of Realism in the Educational Process of the Institute of Dentistry
}

\author{
A. V. Sevbitov, M. Yu. Kuznetsova, A. A. Davidiants, V. V. Borisov, A.E. Dorofeev \\ and A. V. Timoshin \\ Department of Propaedeutics of dental diseases, Sechenov University, Moscow, Russian Federation; \\ avsevbitov@mail.ru,mary-smith@yandex.ru, allshakar@yandex.ru,karapeta@yandex.ru, \\ aedorofeev88@gmail.com, avtimosin91@mail.ru
}

\begin{abstract}
A student at a medical school must know and be able to perform the necessary set of medical manipulations. Simulation training, as an obligatory component of vocational training, provides each trainee with the opportunity to perform professional activities in accordance with professional standards of medical care. Objectives: The goal of the work was the introduction of digital technologies in the educational process. That will allow one to better assess the level of knowledge of students. Methods/Statistical Analysis: The study was conducted in 4 stages: a questionnaire, to determine the initial level of knowledge; theoretical lesson with students; development of manual skills on the simulator; control of acquired knowledge and skills. Findings: The increase in life expectancy, the increase in material and technical equipment and, in general, the increase in the percentage ratio of patients of elderly and senile age dictates the need to take into account not only the characteristics of metabolism and drug interaction, but also the probability of emergence of emergency conditions at the doctor's appointment. In this regard, students should be ready not only to provide urgent help, but also to orient themselves in the office. Application/Improvements: The use of simulators of the 5 th level of realism fully meets the modern requirements of education and can be applied in educational institutions.
\end{abstract}

Keywords: Cardiopulmonary Resuscitation, Dentistry, Education, Simulators

\section{Introduction}

Active development and introduction of digital technologies in the educational process allows not only to qualitatively assess the level of knowledge obtained, but also on the example of a dentist training allows modeling the main stages of the treatment process ${ }^{\underline{1-4}}$.

A student of a medical university must know and be able to perform the necessary set of medical manipulations. Simulation training, as an obligatory component of professional training, provides to each trainee the opportunity to perform professional activities in accordance with professional standards (orders) of medical care $\mathrm{e}^{5-8}$.

The world has accumulated quite a lot of experience in the field of simulation. Nevertheless, the technique of applying and assessing the quality of simulation technologies in medicine is still ambiguous. The following questions remain open: the frequency of the training, the method of teaching, the model of the simulation scenario, and the parameters of assessing the work of the student ${ }^{9-11}$.

${ }^{*}$ Author for correspondence 
Simulation training is becoming an important stage in the practical training of doctors. But it is important to determine at which stage of the implementation of training programs which simulators should be used. The introduction of the system of simulation training in the field of health care allows using it for an objective assessment of the level of practical skill12-14.

\section{Materials and Methods}

The work was done at Sechenov University with the support of the 5 top100 program.

The simulation form of the training process, in which the trainee acts in a specially created imitation environment, is the most acceptable. The main qualities of simulation training are the completeness and realism of modeling an object in a certain situation, which makes it possible to acquire the necessary theoretical and practical knowledge, to develop specific skills without harming human health (Figure 1). Undoubtedly, the most urgent field of medicine, where this training method can and should be used, is ambulance service and emergency medical care.

A number of authors consider the principle of consecutive education, which consists of the following stages:

1. Questioning of students to identify the initial level of knowledge and skills of cardiopulmonary resuscitation,

2. Visual theoretical preparing in the form of lectures and seminars using presentations,

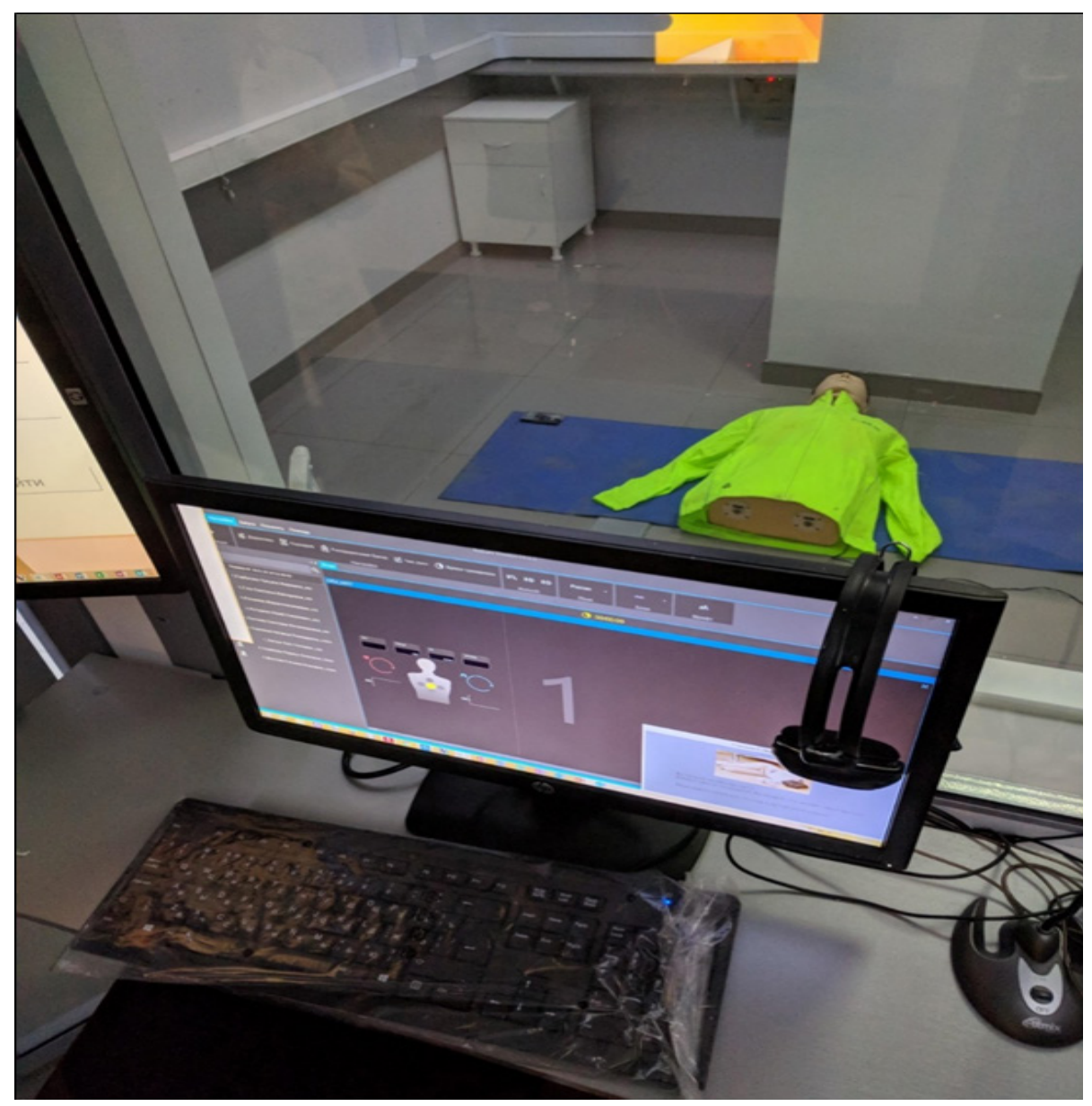

Figure 1. Simulator for cardiopulmonary resuscitation. 
3. Practical mastering of the algorithm for performing cardiopulmonary resuscitation and working out the manipulations under the guidance with discussion of errors and subsequent independent fixation of the technique, and

4. An examination with a separate assessment of the final theoretical knowledge and practical skills.

\section{Results and Discussions}

Conducting sequential (stage-by-stage) simulation training in cardiopulmonary resuscitation technique allows increasing efficiency of theoretical and practical training of students in a short time.

For implementation the phased training we chose simulators of the 5 th level of realism, on which it is possible to simulate the situation of the dental office, where the phantom of the $3 \mathrm{rd}$ level of realism is located.

The task of this level is the imitation of the medical environment and the formation of work skills in conditions close to real.

As a result of work on the level 5 simulators, the student learns the skills and features of the operation of equipment assigned to a specific medical unit. Real ergonomics allows developing a more precise sequence of actions, features of movement in space and increasing the level of motor skills.

The example is the imitation of the emergency condition in a dental office: a simulator of the 3rd level of realism is used as a patient to practice the skills of providing cardiopulmonary resuscitation. Efficiency and speed of rehabilitation occupy an important place in dentistry.

\section{Conclusions}

The relevance of the choice is related to the growing need of physicians in the knowledge and skills to provide CPR. The increasing of life expectancy, the increasing in material and technical equipment and, in general, the increasing of the percentage ratio of elderly and senile patients dictates the need to take into account not only the characteristics of metabolism and drug interactions, but also the probability of emergency conditions at the doctor's office. In this regard, students should be ready not only to provide urgent help, but also to orient themselves in the doctor's office. The using of phantoms of the 5 th level of realism fully meets the requirements and can be applied in educational institutions.

\section{References}

1. Sevbitov AV, Platonova VV, Mironov SN, Dorofeev AE, Pustokhina IG. Experimental substantiation of the bactericidal effect of sodium hypochlorite on the microflora of a purulent wound with odontogenic phlegmons of the face and neck, Indo American Journal of Pharmaceutical Sciences. 2018; 5(3):1635-37.

2. Utyuzh AS, Yumashev AV, Mikhailova MV. Spectrographic analysis of titanium alloys in prosthetic dentistry, Journal of Global Pharma Technology. 2016; 8(12):7-11.

3. Ershov KA, Sevbitov AV, Dorofeev AE, Pustokhina IG. Evaluation of elderly patient's adaptation to removable dentures, Indo American Journal of Pharmaceutical Sciences. 2018; 5(3):1638-41.

4. Kuznetsova M, Nevdakh AS, Platonova VV, Sevbitov AV, Dorofeev AE. Evaluation of effectiveness of a preparation on the basis of phytoecdysteroids for treatment of traumatic injuries of oral mucosa in orthodontic patients, International Journal of Green Pharmacy. 2018; 12(1):297300 .

5. Sevbitov AV, Vasilev YuL, Kanukoeva EYu, Drobot GV, Platonova VV, Dorofeev AE. Analysis of the perception of pain of elderly patient's during surgical dental appointment, Vestnik SPbSU. Medicine. 2017; 12(2):170-78.

6. Yumashev AV, Gorobets TN, Admakin OI, Kuzminov GG, Nefedova IV. Key aspects of adaptation syndrome development and anti-stress effect of mesodiencephalic modulation, Indian Journal of Science and Technology. 2016; 9(19):1-10.

7. Timoshin AV, Sevbitov AV, Drobot GV, Yumashev AV, Timoshina MD. Use of bioresorbable plates on the basis of collagen and digestase for treatment of diseases of oral mucosa (review of clinical cases), International Journal of Green Pharmacy. 2018; 12(1):290-96.

8. Yumashev AV, Utyuzh AS, Volchkova IR, Mikhailova MV, Kristal EA. The influence of mesodiencephalic modulation on the course of postoperative period and osseointegration quality in case of intraosseus dental implantation, Indian Journal of Science and Technology. 2016; 9(42):1-10.

9. Timoshin AV, Sevbitov AV, Ergesheva EV, Boichuk AV, Sevbitova MA. Experience of treatment of aphthous lesions 
of oral mucosa by preparations on the basis of collagen and digestase, Asian Journal of Pharmaceutics. 2018; 12(1):28487.

10. Borisov VV. Using ultraviolet containers for storage and transportation of mouthguards. Indo American Journal of Pharmaceutical Sciences. 2018, 5(2), pp. 1322-26.

11. Evstratenko VV, Sevbitov AV, Platonova VV, Selifanova EI, Dorofeev AE. Distinctive features of crystallization of mixed saliva in patients taking heroin and methadone, Klinichescheskaya laboratornaya diagnostika. 2018; 63(4):223-27.

12. Akhmetshin EM, Morozov IV, Pavlyuk AV, Yumashev AV, Yumasheva NA, Gubarkov SV. Motivation of personnel in an innovative business climate, European Research Studies Journal. 2018; 21(1):352-61.

13. Platonova VV, Sevbitov AV, Shakaryants AA, Dorofeev AE. Experimental and clinical substantiation of treatment of patients having odontogenous phlegmons of maxillofacial region with use of preparation dalargin in complex therapy, Klinichescheskaya laboratornaya diagnostika. 2018; 63(5):293-96.

14. Borisov VV, Sevbitov AV, Poloneichik NM, Voloshina IM. Use of vector patterns for manufacturing of individual protective dental splints by method of thermoforming, Indo American Journal of Pharmaceutical Sciences. 2018; 5(1):697-99. 